\title{
PERSPECTIVE OF COGNITIVE THINKING AND REFLECTIVE TEACHING PRACTICE
}

Dr. Jelena Maksimović, University of Niš, Faculty of Philosophy, E-mail: jelena.maksimovic@filfak.ni.ac.rs MA Jelena Osmanović, University of Niš, Faculty of Philosophy, E-mail: osmanovic.jelena@gmail.com

ART I C LE IN F O

Original Research

Received: April, 27.2019.

Revised: June, 14.2019.

Accepted: July, 01.2019.

doi:10.5937/IJCRSEE1902001M

UDK

159.955.4.075:371.12(497.11)

Keywords:

cognitive thinking,

permanent improvement,

self-evaluation

reflectivity,

teaching practice.

\begin{abstract}
A B S T R A C T
The factor analysis was used to ascertain the factors reflecting the most important attitudes of the respondents concerning reflective thinking in the classroom: self-evaluation, feedback and recording, improvement and analysis of teaching materials, assessment, concepts and misconceptions, construction of knowledge, metacognition and permanent improvement. The results of this research showed statistically significant differences among the aforementioned factors concerning the cycle of education (elementary school teachers and middle school teachers) and work experience (0-5, $6-10 ; 11-20$; over 20 years of experience). The differences were obtained by parametric statistics, calculated using the $t$ test and ANOVA test, $\mathrm{p}<0.05$.
\end{abstract}

(c) 2019 IJCRSEE. All rights reserved.

\section{INTRODUCTION}

Reflective thinking has been discussed in the works of Dewey (1933) and Schön (1983). Dewey (1933, p. 9) asserts that reflection represents an active, permanent and careful consideration of any conviction or knowledge regarding its basic principles and further implications. This assertion demonstrates that reflection is a dynamic type of learning through understanding, changes, evaluation, estimation, analysis and synthesis, as well as a particular problem-solving technique based on an active change, careful gathering and association of ideas. Several decades later, Schön $(1983 ; 1987)$ defines reflection as an advanced mental process that reaches beyond technical reality and involves intuition, insight and skilfullness, and is related to action and reflective practice (reflection-in-action and reflectionon-action). He particularly emphasizes critical reflection which he identifies with critical thinking. Thus, numerous authors identify

Corresponding Author

Dr. Jelena Maksimović, University of Niš, Faculty of Philosophy, E-mail: jelena.maksimovic@filfak.ni.ac.rs

This work is licensed under a Creative Commons Attribution - NonCommercial - NoDerivs 4.0. The article is published with Open Access at www.ijcrsee.com reflection with critical thinking which is related to constant introspection, review of personal thinking and permanent improvement and education (Feucht et al., 2017; Impedovo and Khatoon Malik, 2016; Ryan and Bourke, 2013; Roberts, 2016; Dyankova, 2018).

Ennis (2011a, 2011b, 1989), Scriven and Paul (1987) agree that critical thinking is focused on decision-making about action, reflective processes, alternative points of view concerning problems and queries, potential solutions. It is an intellectual process of an active conceptualization, application, analysis, synthesis and assessment of information obtained by observation, experience, reflection, communication and is based on universal intellectual standards of clarity, precision, accuracy, consistency and relevancy.

Critical thinking requires certain skills (Arsal, 2017; Facione and Gittens, 2013; Pithers and Soden, 2000), such as: focusing on the problem, defining assumptions related to the problem, inductive and deductive reasoning, assessment of reliability of assumptions and sources of information, analysis, generalization, analogy, evaluation, deduction, interpretation, explanation, self-regulation, problem-solving, participation, discussion and estimation.

Reflection occupies an important place in the education of teachers in Serbia and is particularly highlighted in The Rulebook on 
Continuing Professional Development and Advancement of Teachers, which are the documents that accentuate the necessity of the reflective practice in education.

The Rulebook on Continuing Professional Development and Advancement of Teachers (Official Gazette of RS, no. 81/2017) asserts basic rules related to teachers regarding their careers. These guidelines demand from teachers to demonstrate competence in a number of areas, including professional learning. The standards based on teachers' reflective abilities include the following: 1 . Competence in the area of teaching, school subject and teaching methods (the teacher accomplishes functional and educational goals in accordance with general principles, goals and results of education, syllabus and curriculum of the subject taught, adapting them to their pupils' individual characteristics and abilities; continuously supervises and evaluates pupils' accomplishments using various ways of evaluation in accordance with the particular characteristics of the subject taught; prepares classes acknowledging accomplishment standards, teaching plans and programmes and pupils' individual differences); 2. Competence concerning teaching and learning (the teacher supervises and evaluates pupils' accomplishments and their self-evaluation; allows pupils to actively participate in teaching and learning; encourages pupils to express their own ideas freely, to ask questions, discuss and comment teaching topics; continuously stimulates the development and application of various thinking skills (problem-identifying problem-solving, decision-making) and forms of thinking (critical, analytical and divergent); plans activities according to pupils' knowledge and experience, their individual characteristics and needs, determined goals, results, contents and characteristics of the teaching surrounding; gives clear instructions and directs pupils to the transfer of knowledge); 3. Competence in stimulating the development of the pupil's personality (the teacher takes into account individual characteristics and the advancement level of each pupil when preparing and planning various educational and teaching activities; encourages pupils' motivation for learning; encourages and initiates pupils' personal responsibility for learning; plans the interaction of all those who are involved in education, which is based on the respect of differences and recognition of needs; considers pupils' opinion when evaluating their accomplishments; encourages initiative and free expression of pupils' thoughts, attitudes and convictions; respects the person- ality and privacy of all pupils; evaluates their own work by the analysis and supervision of motivation, satisfaction, pupils' attentiveness in class, their independence and perseverance); 4. Competence in communication and cooperation (the teacher plans teaching as a member of a team; promotes initiative and free expression of pupils' thoughts, attitudes and convictions).

These standards stress the necessity of realizing one's own personal and professional work and they identify the necessity to improve skills and knowledge and to include other colleagues and larger networks of education workers into the improvement of teaching practice. Reflection is an important component of the programmes for the education of teachers. As regards the teachers in Serbia, reflection represents a rather contemporary issue which is the focus of this research.

\section{MATERIALS AND METODS 2.1. The goal of the research}

The significance of reflective practice in the context of schools, teaching and teachers' work has been discussed quite frequently. Reflection, reflective practice and reflective thinking are very important elements of both efficient teaching and professional development of teachers. The goal of contemporary teaching is the improvement of these concepts. The goal of this research is not only the indication of the importance of teachers' reflection but also the examination of teachers' attitudes to reflection in teaching practice.

\subsection{Variables}

The research established two independent variables. The first independent variable involves the education cycle which is operationalized into two categories comprised of elementary school teachers and middle school teachers. The second independent variable is teachers' work experience which is operationalized into four categories: teachers with 0 to 5 years of experience, those with 6 to 10 years of teaching experience, respondents with 11 to 20 years of experience in teaching and teachers with 20 years and more.

\subsection{Methods and Instruments}

Data were collected using the descriptive method and the scaling technique. The Likert- 
type scale was used to assess the results (from 1 - strongly disagree to 5 - strongly agree). A similar research was conducted by Hamilton (2005) who also explored three main areas of reflection: the ability of self-reflection, the manner of learning and the development of the skills of life-long learning. The instrument contained 33 items. Two independent variables were implemented in this instrument for this research: education cycle and work experience.

\subsection{Respondents}

The sample of this research is deliberate. 1220 primary school teachers from Serbia participated in the research.

The following graphs show the structure of the respondents and their homogeneity regarding the independent variables.

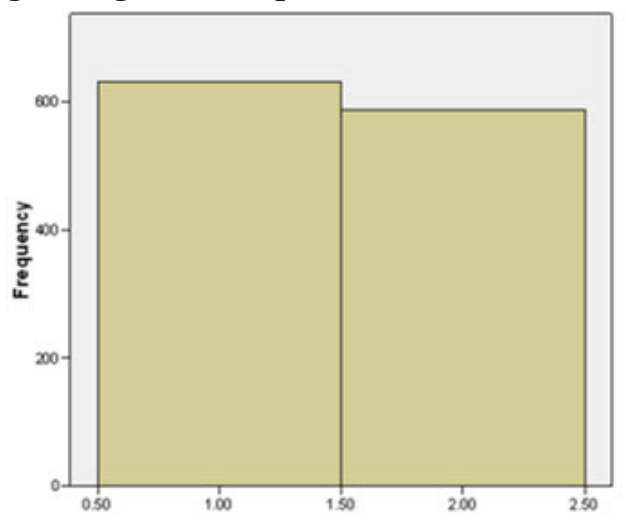

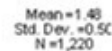

Graph 1: Structure of respondents regarding education cycle

1220 respondents participated in the research $(\mathrm{N}=1220), 632$ elementary school teachers and 588 middle school teachers $(\mathrm{M}=1.48 ; \mathrm{SD}=0.50)$.
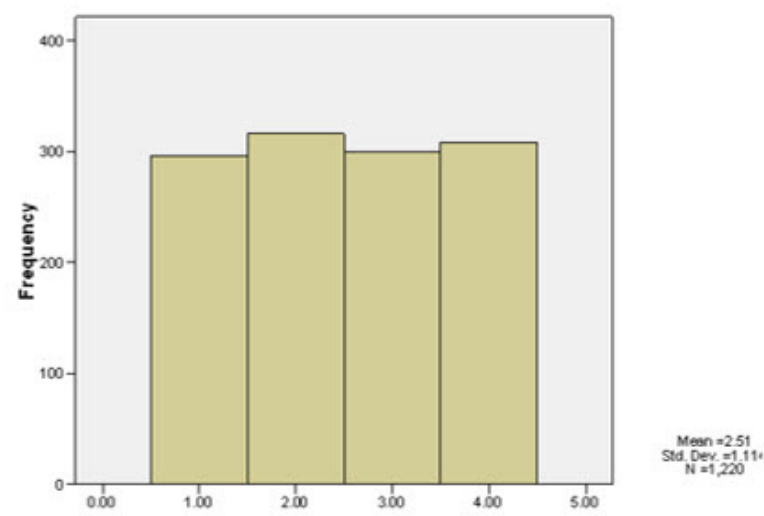

Graph 2: Structure of respondents regarding years of work experience
The number of respondents $(\mathrm{N}=1220)$ considering their work experience: 296 teachers with 0 to 5 years, 316 with 6 to 10 years, 300 with 11 to 20 years and 300 teachers with 20 and more years of teaching experience. This proves a relatively homogenous structure of the respondents $(\mathrm{M}=2.51 ; \mathrm{SD}=1.22)$.

\section{RESULTS}

The factor analysis was used to test the scale structure and it confirmed the factor structure of the instrument created by the authors Choy, S. C. and Oo. Pou San (2012). KiaserMeyer-Olkin test was 0.78, whereas Bartlett's test of the statistical significance showed a statistically significant result $(\mathrm{p}=0.00)$, which justified the use of the factor analysis in this research (Table 1$)$.

Table 1. KMO and Bartlett's Test

\begin{tabular}{|c|c|c|}
\hline \multicolumn{2}{|c|}{$\begin{array}{c}\text { Kaiser-Meyer-Olkin } \\
\text { Measure of Sampling } \\
\text { Adequacy. }\end{array}$} & 0.780 \\
\hline \multirow{3}{*}{$\begin{array}{l}\text { Bartlett's } \\
\text { Test of } \\
\text { Sphericity }\end{array}$} & $\begin{array}{c}\text { Approx. } \\
\text { Chi-Square }\end{array}$ & 18999.041 \\
\hline & df & 528 \\
\hline & Sig. & 0.000 \\
\hline
\end{tabular}

The factor analysis of the data extracted eight main factors that explained $63.63 \%$ of the variance (Table 2). The factor analysis extracted main research factors that were further statistically processed and analyzed. 
Table 2. Factor analysis -factor extraction

\begin{tabular}{|c|c|c|c|c|c|c|}
\hline \multirow[t]{2}{*}{ Component } & \multicolumn{3}{|c|}{ Initial Eigenvalues } & \multicolumn{3}{|c|}{ Extraction Sums of Squared Loadings } \\
\hline & Total & $\begin{array}{c}\% \text { of } \\
\text { Variance } \\
\end{array}$ & $\begin{array}{c}\text { Cumulative } \\
\% \\
\end{array}$ & Total & $\begin{array}{c}\% \text { of } \\
\text { Variance } \\
\end{array}$ & $\begin{array}{c}\text { Cumulative } \\
\% \\
\end{array}$ \\
\hline 1 & 6.926 & 20.987 & 20.987 & 6.926 & 20.987 & 20.987 \\
\hline 2 & 4.648 & 14.084 & 35.071 & 4.648 & 14.084 & 35.071 \\
\hline 3 & 2.159 & 6.541 & 41.613 & 2.159 & 6.541 & 41.613 \\
\hline 4 & 1.693 & 5.129 & 46.742 & 1.693 & 5.129 & 46.742 \\
\hline 5 & 1.568 & 4.751 & 51.493 & 1.568 & 4.751 & 51.493 \\
\hline 6 & 1.514 & 4.587 & 56.081 & 1.514 & 4.587 & 56.081 \\
\hline 7 & 1.332 & 4.036 & 60.116 & 1.332 & 4.036 & 60.116 \\
\hline 8 & 1.071 & 3.244 & 63.361 & 1.071 & 3.244 & 63.361 \\
\hline 9 & .986 & 2.987 & 66.348 & & & \\
\hline 10 & .963 & 2.920 & 69.268 & & & \\
\hline 11 & .904 & 2.739 & 72.006 & & & \\
\hline 12 & .783 & 2.371 & 74.378 & & & \\
\hline 13 & .723 & 2.190 & 76.568 & & & \\
\hline 14 & .690 & 2.091 & 78.659 & & & \\
\hline 15 & .668 & 2.025 & 80.684 & & & \\
\hline 16 & .603 & 1.828 & 82.511 & & & \\
\hline 17 & .581 & 1.762 & 84.273 & & & \\
\hline 18 & .533 & 1.615 & 85.888 & & & \\
\hline 19 & .509 & 1.542 & 87.430 & & & \\
\hline 20 & .462 & 1.399 & 88.829 & & & \\
\hline 21 & .439 & 1.330 & 90.159 & & & \\
\hline 22 & .422 & 1.277 & 91.436 & & & \\
\hline 23 & .403 & 1.222 & 92.659 & & & \\
\hline 24 & .348 & 1.055 & 93.713 & & & \\
\hline 25 & .330 & .999 & 94.712 & & & \\
\hline 26 & .293 & .888 & 95.600 & & & \\
\hline 27 & .258 & .781 & 96.380 & & & \\
\hline 28 & .251 & .759 & 97.140 & & & \\
\hline 29 & .226 & .684 & 97.823 & & & \\
\hline 30 & .204 & .619 & 98.443 & & & \\
\hline 31 & .180 & .546 & 98.988 & & & \\
\hline 32 & .175 & .530 & 99.518 & & & \\
\hline 33 & .159 & .482 & 100.000 & & & \\
\hline
\end{tabular}

\section{Extraction Method: Principal Component Analysis.}

The factor analysis extracted the following factors:

1. Self-evaluation (I always think about what I do in classes in order to improve myself; I prefer obeying orders to being innovative in order to avoid trouble; I try to think about the materials I teach in order to improve my lectures).

2. Feedback and recording (I feel concerned about the feedback I get from my pupils since it is the assessment of and opinion about my personality; I think that the feedback obtained from my pupils is important because it helps me to understand them better; I consider the feedback I get from my pupils im- portant because it is an indicator of my strong points and my drawbacks).

3. Improvement and analysis of teaching materials (I assume that my teaching method and teaching materials are indicators of my efficiency; I know that there may be some segments, such as particular materials and contexts, which may either improve or downgrade the lecture; I always try to connect the materials I teach to my life experience).

4. Assessment (I regard my mistakes as some experience that will help me to do better in the future; I know that I make mistakes but I sometimes think that I cannot do anything about that; Being a teacher, I am fully aware of 
the fact that my mistakes may have an impact on the lives of my pupils).

5. Concepts and misconcetions (I do not take into account the feedback obtained from my pupils; I dismiss it as being merely their opinion; I disregard it as long as I believe I do my work well; I think that the feedback obtained from my pupils is important because it helps me to correct my teaching methods, which will guarantee my better performance in class; I am willing to consider my previous lectures and integrate them into my present teaching in order to be better prepared for the future work).

6. Construction of knowledge (I show interest only in the class I teach, I basically have no time for or interest in talking to colleagues about the teaching strategies and goals they establish in their classes; I want to know how effective my teaching is, so any feedback from my superiors is useful for me; My pupils do not learn in the same way as I used to, so I need to examine new teaching strategies in order for them to remain relevant in the future).

7. Metacognition (I teach in a certain way that suits me, I do not know why I teach like that but I simply do; I want to do my own, individual research in order to gain certain knowledge on how to teach or how to educate myself to become a better teacher; I try to think about my lectures and teaching so that I can improve and inhance teaching strategies and use novel and efficient ones; Sometimes I may obtain some information from conversations with colleagues who teach different subjects).

8. Permanent improvement (The feedback that I get from my pupils and my superiors is sometimes so vague that I do not know how to proceed with it; I do not think that the feedback can help me to learn how to teach better; I am aware that I am still learning to become a better teacher and that this process can be facilitated by the feedback obtained from my pupils and my superiors; I know that I have learnt about my profession all my life; I have already encountered some problems that I have overcome owing to my resourcefulness, but I still think the feedback from my pupils and superiors would be very helpful in the improvement of my teaching). 
Table 3. Differences in respondents' opinions regarding the education cycle

\begin{tabular}{|c|c|c|c|c|c|c|c|}
\hline & $\begin{array}{l}\text { Education } \\
\text { cycle }\end{array}$ & $\mathrm{N}$ & M & $\mathrm{SD}$ & $\mathrm{t}$ & df & $\mathrm{p}$ \\
\hline SELF-EVALUATION & $\begin{array}{c}\text { Elementary } \\
\text { school } \\
\text { teachers } \\
\text { Middle } \\
\text { school } \\
\text { teachers }\end{array}$ & 588 & 12.29 & 1.64 & -3.05 & 1218 & 0.00 \\
\hline FEEDBACK & $\begin{array}{c}\text { Elementary } \\
\text { school } \\
\text { teachers } \\
\text { Middle } \\
\text { school } \\
\text { teachers }\end{array}$ & 632 & 12.11 & 1.78 & -0.45 & 1218 & 0.65 \\
\hline $\begin{array}{l}\text { ANALYSIS OF } \\
\text { TEACHING } \\
\text { MATERIALS }\end{array}$ & $\begin{array}{c}\text { Elementary } \\
\text { school } \\
\text { teachers } \\
\text { Middle } \\
\text { school } \\
\text { teachers }\end{array}$ & 632 & 13.09 & 1.61 & -1.32 & 1218 & 0.18 \\
\hline ASSESSMENT & $\begin{array}{c}\text { Elementary } \\
\text { school } \\
\text { teachers } \\
\text { Middle } \\
\text { school } \\
\text { teachers }\end{array}$ & 632 & 10.68 & 1.86 & -1.90 & 1218 & 0.05 \\
\hline $\begin{array}{c}\text { CONCEPTS } \\
\text { MISCONCEPTIONS }\end{array}$ & $\begin{array}{c}\text { Elementary } \\
\text { school } \\
\text { teachers } \\
\text { Middle } \\
\text { school } \\
\text { teachers }\end{array}$ & 632 & 10.83 & 1.57 & -1.23 & 1218 & 0.21 \\
\hline $\begin{array}{l}\text { CONSTRUCTION OF } \\
\text { KNOWLEDGE }\end{array}$ & $\begin{array}{c}\text { Elementary } \\
\text { school } \\
\text { teachers } \\
\text { Middle } \\
\text { school } \\
\text { teachers }\end{array}$ & 632 & 10.61 & 1.65 & -3.71 & 1218 & 0.00 \\
\hline METACOGNITION & $\begin{array}{c}\text { Elementary } \\
\text { school } \\
\text { teachers } \\
\text { Middle } \\
\text { school } \\
\text { teachers }\end{array}$ & 632 & 11.50 & 1.67 & -2.25 & 1218 & 0.02 \\
\hline $\begin{array}{l}\text { PERMANENT } \\
\text { LEARNING }\end{array}$ & $\begin{array}{c}\text { Elementary } \\
\text { school } \\
\text { teachers } \\
\text { Middle } \\
\text { school } \\
\text { teachers }\end{array}$ & 588 & 11.25 & 1.73 & -1.58 & 1218 & 0.11 \\
\hline
\end{tabular}

Table 3 shows the differences in the respondents' opinions as regards the education cycle. The difference is statistically significant in relation to the factors Self-evaluation, Assessment, Construction of knowledge and Metacognition and is $p<0.05$. The comparison of the arithmetic means proves that those items that are characterized by a statistically significant difference were valued more positively by middle school teachers than by elementary school teachers. The reasons for this can be various. For instance, Serbian middle school teachers teaching from the fifth to the eight grade are more experienced and teach many more classes than elementary school teachers, who teach only one class. On the other hand, one must not overlook the fact that teachers teaching higher grades are experts in their teaching areas. They teach only one school subject, which means that their reflection is focused on the evaluation of their work concerning only one teaching area, whereas elementary school teachers need to reflect on a number of different school subjects and transfer their knowledge to their pupils, but also to critically reconsider the results of their teaching and all the elements of reflection concerning various teaching areas. In comparison to middle school teachers, self-evaluation, assessment, adaptation of knowledge to different pupils from different classes are the factors that are prevalent among elementary school teachers. Other factors, such as Feedback, Analysis of teaching materials, Concepts and misconceptions, do not show any statistically significant difference. The answers of both categories of respondents are homogeneous, $p>0,05$. Table 4. Differences in respondents' opinions regarding years of work experience Table 4. Differences in respondents' opinions regarding years of work experience. 
Table 4. Differences in respondents' opinions regarding years of work experience

\begin{tabular}{|c|c|c|c|c|c|c|}
\hline & & $\mathrm{N}$ & M & SD & $\mathrm{F}$ & $p$ \\
\hline \multirow{5}{*}{ SELF-EVALUATION } & $0-5$ & 296 & 12.25 & 1.73 & 2.028 & 0.10 \\
\hline & $6-10$ & 316 & 12.58 & 1.82 & & \\
\hline & $11-20$ & 300 & 12.48 & 1.63 & & \\
\hline & over 20 & 308 & 12.40 & 1.49 & & \\
\hline & Total & 1220 & 12.43 & 1.68 & & \\
\hline \multirow{5}{*}{ FEEDBACK } & $0-5$ & 296 & 12.02 & 1.98 & 10.231 & 0.00 \\
\hline & $6-10$ & 316 & 11.70 & 2.23 & & \\
\hline & $11-20$ & 300 & 12.46 & 1.77 & & \\
\hline & over 20 & 308 & 12.36 & 1.48 & & \\
\hline & Total & 1220 & 12.13 & 1.91 & & \\
\hline \multirow{5}{*}{$\begin{array}{l}\text { ANALYSIS OF } \\
\text { TEACHING MATERIALS }\end{array}$} & $0-5$ & 296 & 13.27 & 1.31 & 5.302 & 0.00 \\
\hline & $6-10$ & 316 & 13.20 & 1.58 & & \\
\hline & $11-20$ & 300 & 13.30 & 1.40 & & \\
\hline & over 20 & 308 & 12.84 & 2.03 & & \\
\hline & Total & 1220 & 13.15 & 1.61 & & \\
\hline \multirow{5}{*}{ ASSESSMENT } & $0-5$ & 296 & 10.89 & 2.26 & 1.555 & 0.19 \\
\hline & $6-10$ & 316 & 10.79 & 1.92 & & \\
\hline & $11-20$ & 300 & 10.88 & 1.77 & & \\
\hline & over 20 & 308 & 10.59 & 1.60 & & \\
\hline & Total & 1220 & 10.79 & 1.90 & & \\
\hline \multirow{5}{*}{$\begin{array}{l}\text { CONCEPTS AND } \\
\text { MISCONCEPTIONS }\end{array}$} & $0-5$ & 296 & 11.06 & 1.86 & 1.746 & 0.15 \\
\hline & $6-10$ & 316 & 10.89 & 1.42 & & \\
\hline & $11-20$ & 300 & 10.82 & 1.65 & & \\
\hline & over 20 & 308 & 10.77 & 1.65 & & \\
\hline & Total & 1220 & 10.89 & 1.65 & & \\
\hline \multirow{6}{*}{$\begin{array}{l}\text { CONSTRUCTION OF } \\
\text { KNOWLEDGE }\end{array}$} & $0-5$ & 296 & 11.04 & 1.82 & 3.795 & 0.01 \\
\hline & $6-10$ & 316 & 10.86 & 1.59 & & \\
\hline & & & & & & \\
\hline & $11-20$ & 300 & 10.60 & 1.86 & & \\
\hline & over 20 & 308 & 10.67 & 1.72 & & \\
\hline & Total & 1220 & 10.79 & 1.75 & & \\
\hline \multirow{5}{*}{ METACOGNITION } & $0-5$ & 296 & 11.67 & 1.75 & 6.324 & 0.00 \\
\hline & $6-10$ & 316 & 11.79 & 1.61 & & \\
\hline & $11-20$ & 300 & 11.44 & 1.70 & & \\
\hline & over 20 & 308 & 11.40 & 1.54 & & \\
\hline & Total & 1220 & 11.60 & 1.66 & & \\
\hline \multirow{5}{*}{$\begin{array}{l}\text { PERMANENT } \\
\text { LEARNING }\end{array}$} & $0-5$ & 296 & 11.36 & 1.64 & 2.473 & 0.06 \\
\hline & $6-10$ & 316 & 11.11 & 1.50 & & \\
\hline & $11-20$ & 300 & 11.21 & 1.72 & & \\
\hline & over 20 & 308 & 11.01 & 1.74 & & \\
\hline & Total & 1220 & 11.17 & 1.66 & & \\
\hline
\end{tabular}

Table 4 shows the differences in the respondents' replies with regard to their work experience. The results were obtained using the ANOVA statistical technique. The differences were evident in the replies concerning the following factors: Feedback, Construction of knowledge and Metacognition, and they were $\mathrm{p}<0.05$.

In comparison to younger colleagues, the teachers with more years of work experience (11-20 and over 20 years of teaching experience) appreciated more the importance of the feedback obtained from their pupils. Moreover, the teachers with 11 to 20 years of work experience, with the highest arithmetic mean (Table 4), differ from less experienced colleagues regarding their opinions on the analysis of teaching materials, particularly the relationship between the materials they teach and their life experience. This difference is not surprising since the years of teaching experience can considerably influence all segments of teaching and all contexts that can contribute to the improvement of teaching methods, and it was $p<0,05$. Young teachers suggested that pupils should acquire knowledge in a different way when compared to traditional education, which is the reason why they endeavoured to enrich their teaching strategies by introducing novel and more efficient ones. Also, young teachers developed metacognition, they learned how to become better in their profession and sought advice from other colleagues. As regards the examined statements, it does not surprise that young teachers valued more Construction of knowledge and Metacognition, $\mathrm{p}<0.05$.

\section{DISCUSSION}

Education in the Republic of Serbia is supervised by the Ministry of Education, Science and Technological Development. It is 
divided into preschool (kindergartens), primary (elementary schools), secondary (high schools) and tertiary education (higher education schools of professional studies, faculties and universities). Primary education is subdivided into two cycles: the first cycle (from the first to the fourth grades, taught by elementary school teachers) and the second cycle (from the fifth to the eighth grades, taught by middle school teachers).

This research examined teachers' attitudes to reflection in primary school education. Two independent variables, education cycle and years of work experience, were used in the reasearch. The education cycle was operationalized into two categories: elementary school teachers (from the first to the fourth grade) and middle school teachers (from the fifth to the eighth grade), while the second variable, the years of teaching experience, was operationalized into four categories: (05 ; 6-10, 11-20; over 20 years of work experience). The research demonstrated statistically significant differences in the respondents' replies concerning the factors such as Self-evaluation, Assessment, Construction of knowledge, Metacognition, $p<0.05$. The observed difference showed that these factors were evaluated more positively by middle school teachers than by elementary school teachers. Moreover, a statistically significant difference was observed regarding the years of work experience, which confirmed that work experience could affect all segments of teaching and all contexts that can contribute to the improvement of teaching, $p<0,05$. Young teachers suggest that pupils should be taught in a different, less traditional way and endeavour to enrich their teaching strategies. A number of contemporary authors (Cunliffe, 2016; Gorli, Nicolini and Scaratti, 2015; Pässilä, Oikarinen and Harmaakorpi, 2015; Ripamonti et al., 2016) have conducted theoretical and empirical research on the contribution of reflective practice to teaching efficiency. The results of these studies prove that reflective practice helps teachers to abandon impulsive and routine practice, create their daily tasks, act purposefully and appropriately, increase their own awareness of teaching, improve understanding and introduce positive changes.

Our reasearch confirmed these results. It is important to constantly reassess the quality of teaching and exclude traditional teaching methods. The principles and strategies of teaching obtained from this research are expected to be applied in practice with the purpose of improving teachers' reflection, both personal and professional, and their teaching methods. Therefore, their self-confidence will increase and their skills will be improved, which will all be very helpful in future challenging and demanding tasks imposed on them not only by the government documents but also by the altered roles in their professional work.

\section{CONCLUSION}

Contemporary society has brought about an altered vision of the teacher who no longer controls the teaching process but becomes an agent of critical change, accepting the role of a critical reflective practicioner. Reflection is beneficial for teachers since it enables them to acknowledge experience, assume a critical attitude towards practice, inhance their awareness of teaching, develop profound understanding, create positive changes (Bognar, 2013; Farrell, 2003). On the other hand, reflective practice is connected to the process of persistent and careful consideration of situations. Only those teachers who reflect on their practice do become more professional and efficient in teaching since only systematic reflection enables teachers to have an influence on making decisions that may cause changes in teaching practice (Larrivee, 2005). Reflective practice helps teachers free themselves from the constraints of a routine and impulsive behaviour.

Who is a teacher who is a reflective practicioner? This question reveals the basis of the definition of a teacher as a reflective practicioner. Reflection (serious thinking) + Practice (activities and action) = Reflective teacher, the teacher who reflects on what they do.

Such a teacher bases their teaching on research and critical consideration of their own actions, considers practice from various perspectives, discovers and understands their own assumptions, develops and changes their own practice and ensuing and relevant consequences. The goal of the reassessment is not for teachers to exclude these implicit pieces of knowledge and principles, but to become aware of them and use them in their teaching purposefully and intentionally. Metaphorically speaking, "The expression a refelective practicioner means that a teacher is supposed to look at their own image in the mirror and think about the reflection of their own teaching practice" (Radulović, 2011, p. 31).

The question may be raised: How new is the idea of reflection? Though rather popular, 
it is not so new. This notion can be found in the works of Dewey (1933) and Schön (1983). The complexity of the teaching profession itself has always forced teachers to reassess and review their work and its results. However, this phenomenon has not been thoroughly examined and recorded. Thus, this research attempted to examine the reflection of teachers working in Serbian primary schools. Judging by the analyzed factors, this research suggests that some further study be conducted in preschool, secondary school and tertiary education. Also, this issue may be explored from the angle of all levels of education in the Republic of Serbia.

The idiosyncrasy of this research is reflection on reflection. Notwithstanding the fact that teachers did not explicitly state what elements of reflection they were thinking about, this research might encourage them to consider their teaching in a different way.

\section{ACKNOWLEDGEMENTS}

The article is the result of work on the project „Pedagogical pluralism as the basis of the education strategy“, number 179036 (2011-2019), wich is financed by the Ministry of Education, Science and Technological Development of the Republic of Serbia.

\section{Conflict of interests}

The authors declare no conflict of interest.

\section{REFERENCES}

Arsal, Z. (2017). The impact of inquiry-based learning on the critical thinking dispositions of pre-service science teachers. International Journal of Science Education, 39(10), 1326-1338. https:// doi.org/10.1080/09500693.2017.1329564

Bognar, B. (2013). Initiating teachers' action research: Empowering teachers' voices. Online Submission, Educational Journal of Living Theories, 6(1), 1-39. https://eric.ed.gov/?id=ED546485

Choy, S. C. \& Oo. Pou San (2012). Reflective Thinking and Teaching Practices: a Precursor For Incorporating Critical Thinking into The Classroom? International Journal of Instruction, 5(1), 167- 182. Retrived from: https://eric. ed.gov/?id=ED529110

Cunliffe, A. L. (2016). "On becoming a critically reflexive practitioner" Redux: What does it mean to be reflexive?. Journal of Management Education, 40(6), 740-746. https://doi. org/10.1177/1052562916668919

Dewey, J. (1933). How we think: A restatement of the relation of reflective thinking to the educative process. Boston; New York: D.C. Heath
\& Company. Retrived from: https://opus4. kobv.de/opus4-Fromm/frontdoor/index/index/ docId/7969

Dyankova, G. (2018). Research of cognitive exchange specifics in teachers academic training. International Journal of Cognitive Research in Science, Engineering and Education (IJCRSEE), 6(3), 1-14. https://doi.org/10.5937/ijcrsee1803001D

Ennis, H. (2011a). Critical thinking: Reflection and perspectives. Part I. INQUIRY: Critical Thinking Across the Disciplines. 26(1), 4-18. https://10.5840/inquiryctnews20112613

Ennis, H. (2011b). Critical thinking: Reflection and perspectives. Part II. INQUIRY: Critical Thinking Across the Disciplines. 26(2), 5-19. https://10.5840/inquiryctnews201126215

Ennis, R. H. (1989). Critical Thinking and Subject Specificity: Clarification and Needed Research. Educational Researcher, 18(3), 4-10. https:// doi.org/10.3102/0013189X018003004

Facione, P., \& Gittens, C. (2013). Think critically (2nd ed.). New York, NY: Pearson.

Farrell, T. S. (2003). Reflective practice in action: 80 reflection breaks for busy teachers. Corwin Press.

Feucht, F. C., Lunn Brownlee, J., \& Schraw, G. (2017). Moving beyond reflection: Reflexivity and epistemic cognition in teaching and teacher education. Educational Psychologist, 52:4, 234-241. https://doi.org/10.1080/00461520.2017.135018 0

Gorli, M., Nicolini, D., \& Scaratti, G. (2015). Reflexivity in practice: Tools and conditions for developing organizational authorship. $\mathrm{Hu}$ man Relations, 68(8), 1347-1375. https://doi. org/10.1177/0018726714556156

Hamilton, S. J. (2005). Development in Reflective Thinking. Abstract retrieved May 25, 2008.

Impedovo, M. A., \& Khatoon Malik, S. (2016). Becoming a Reflective In-service Teacher: Role of Research Attitude. Australian Journal of Teacher Education, 41(1). http://dx.doi.org/10.14221/ ajte. $2016 \mathrm{v} 41 \mathrm{n} 1.6$

Larrivee, B., \& Cooper, J. M. (2005). An educator's guide to teacher reflection. Wadsworth Publishing Company.

Pässilä, A. H., Oikarinen, T., \& Harmaakorpi, V. (2015). Collective voicing as a reflexive practice. Management Learning, 46(1), 67-86. https://doi. org/10.1177/1350507613488310

Pithers, R. T., \& Soden, R. (2000). Critical thinking in education: A review. Educational research, 42(3), 237-249. https://doi. org/10.1080/001318800440579

Pravilnik o stalnom stručnom usavršavanju i napredovanju zvanja nastavnika (Službeni glasnik RS, broj 81/2017) [Official Gazette of RS, no.81/2017] Retrived from: http://www.pravno-informacioni-sistem.rs/SlGlasnikPortal/ viewdoc?uuid $=463157 \mathrm{e} 7-5 \mathrm{f} 31-4 \mathrm{f} 6 \mathrm{f}-\mathrm{b} 8 \mathrm{e} 7$ $9500495 \mathrm{e} 219 \mathrm{a}$

Radulović, L. (2011). Obrazovanje nastavnika za refleksivnu praksu. Beograd: Filozofski fakultet

Ripamonti, S., Galuppo, L., Gorli, M., Scaratti, G., \& Cunliffe, A. L. (2016). Pushing Action Research Toward Reflexive Practice. Journal of Management Inquiry, 25(1), 55-68. https://doi. org/10.1177/1056492615584972

Roberts, P. (2016). Reflection: A renewed and practical focus for an existing problem in teacher education. Australian Journal of Teacher Edu- 
Maksimović, J., \& Osmanović, J. (2019). Perspective of cognitive thinking and reflecive teaching practice, International Journal of Cognitive Research in Science, Engineering and Education (IJCRSEE), 7(2), 1-10

cation, 41(7), 2. http://dx.doi.org/10.14221/ ajte. $2016 \mathrm{v} 41 \mathrm{n} 7.2$

Ryan, M., \& Bourke, T. (2013). The teacher as reflexive professional: Making visible the excluded discourse in teacher standards. Discourse: Studies in the cultural politics of education, 34(3), 411423. https://doi.org/10.1080/01596306.2012.71 7193

Scriven, M. \& Paul, R. (1987). Defining Critical Thinking. Retrieved December from: http:/www. criticalthinking.org/pages/defining-criticalthinking/410

Schön, D. (1983). The Reflective Practioner. New York: Basic Books.

Schön, D. (1987). Education the reflective practitioner. San Francisko: Oxford.

Scriven, M., \& Paul, R. (1996). Defining critical thinking: A draft statement for the National Council for Excellence in Critical Thinking. Retrieved March 23, 2017. Retrived from: http://www. criticalthinking.org/pages/defining-criticalthinking/766 